\title{
Transitional Justice in Brazil and the Jurisprudence of the Inter-American Court of Human Rights: a difficult dialogue with the Brazilian judiciary"
}

\author{
Justiça de Transição no Brasil e a Jurisprudência da Corte Interamericana \\ de Direitos Humanos: a dificuldade do diálogo com o judiciário brasileiro
}

\author{
Bruno Galindo ${ }^{1}$ \\ ${ }^{1}$ Universidade Federal de Pernambuco, Recife - PE, Brasil.
}

\begin{abstract}
The paper will address transitional justice in Brazil, considering the objectives advocated by its general theory. The main idea is to make a legal analysis of the transition process in Brazil based on the relationship between Brazilian constitutional law and the Inter-American Human Rights System. It will be suggested to reflect on the ways of the dialogue between the two systems of protection of human rights (Inter-American and constitutional) proposed by some contemporary theories. As a conclusion, some reflections on how this situation contributes to the current Brazilian political crisis, especially for a certain popularization of authoritarianism as a political solution.
\end{abstract}

Keywords: Brazil. Transitional Justice. InterAmerican System of Human Rights. Crimes against humanity. Authoritarianism.
Resumo: O artigo aborda a justiça de transição no Brasil, considerando os objetivos defendidos pela sua teoria geral. A principal proposta é fazer uma análise jurídica do processo de transição no Brasil com base na relação entre o direito constitucional brasileiro e o Sistema Interamericano de Direitos Humanos. É sugerida uma reflexão sobre os caminhhos de diálogo entre os dois sistemas de proteção dos direitos humanos (interamericano e constitucional) propostos por algumas teorias contemporâneas. Como conclusão, algumas reflexões sobre como essa situação contribui para a atual crise política brasileira, especialmente para certa popularização do autoritarismo como solução política.

Palavras-chave: Brasil. Justiça de Transição. Sistema Interamericano de Direitos Humanos. Crimes contra a humanidade. Autoritarismo.

\footnotetext{
* Talk given in the Weekly Seminar Series of Oxford Transitional Justice Research of the University of Oxford/UK on October 16, 2017, with some adaptations for publication. My special thanks to my dear friends Talita Dias and Daniel Franchini, Convenors of OTJR, and to Professor Carolyn Hoyle, Director of Centre for Criminology, by the immense kindness of the invitation. This text was completed on January 1, 2018.
}

Recebido em: 15/01/2018

Revisado em: 07/07/2018

Aprovado em: 07/08/2018 


\section{Introduction}

This article was written from the Talk given in the Weekly Seminar Series of Oxford Transitional Justice Research of the University of Oxford/UK on October 16, 2017, with some adaptations for publication. Then the Talk was named "Transitional justice in Brazil and the jurisprudence of the Inter-American Court of Human Rights", also subject of our researches at the Law School of the Federal University of Pernambuco, in Brazil, especially in our Postgraduate Program in Law.

The paper is divided into three main parts: First, some considerations about the Inter-American System of Human Rights, its general features and the most important leading cases of the IACHR about transitional justice; Then, the main legal aspects of the last dictatorship and transitional justice in Brazil; And finally, the judicial decisions in opposite senses of the Brazilian Federal Supreme Court and the Inter-American Court of Human Rights, and the possibilities of dialogues between the courts in the context of Brazilian transitional justice, including some theoretical output. As a conclusion, some reflections on how this situation contributes to the current Brazilian political crisis, especially for a certain popularization of authoritarianism as a solution.

\section{Inter-American Court of Human Rights: supranational jurisdiction and Inter-American jurisprudence on transitional justice}

The Inter-American System of Human Rights (IASHR) was founded in 1969 with the signature of the American Convention of Human Rights (ACHR), known as Pact of San José of Costa Rica. It is associated to the Organization of American States (OAS), but with autonomous organisms. These official bodies are the Inter-American Commission on Human Rights, with competence to investigate, make recommendations and refer cases to the Court, and the Inter-American Court of Human Rights (IACHR), whose judges have jurisdiction to interpret and apply 
the Convention. Nowadays, 20 countries in Latin America are fully integrated into the IASHR (GARCÍA RAMÍREZ, 2014, p. 233) ${ }^{1}$.

The IACHR is composed of 7 judges from different nationalities (Statute of IACHR, article 4). The current judges (October 2017) are Roberto Figueiredo Caldas (President/Brazil), Eduardo Ferrer MacGregor (Vice-President/Mexico), Eugenio Raúl Zaffaroni (Argentina), Humberto Sierra Porto (Colombia), Eduardo Vio Grossi (Chile) Elizabeth Odio Benito (Costa Rica) and Patricio Pazmiño Freire (Ecuador).

It's possible to say that IACHR exercises a supranational jurisdiction and controls conventionality in relation to the legal acts of States that are submitted to the optional clause of compulsory jurisdiction. This clause enables the Court to analyze in the case submitted to it if the Convention is being violated by the State and establish its understanding as an official interpreter of the Convention, which, in the case of the countries that have ratified the said clause, is binding for them (ACHR, articles 62/63).

In theoretical terms, it has become common to speak of a doctrine of conventionality control within the framework of the Court's jurisprudence, borrowing some well-known operational concepts from constitutional and international law, such as constitutionality control, constitutionality block, and supranationality (FERRER MACGREGOR, 2015). Such doctrine was conceived by court judges such as Eduardo Ferrer Mac Gregor and Sergio García Ramírez, as well as professors like Nestor Sagües and Victor Bazán (GARCÍA RAMÍREZ, 2014, p. 257; GARCÍA RAMÍREZ \& MORALES SÁNCHEZ, 2016, p. 439; BAZÁN, 2015). The first time it was explicitly mentioned in a case decided by the Court was in Almonacid Arellano versus Chile in 2006, coincidentally involving issues about transitional justice in that country (IACHR. Almonacid Arellano vs. Chile, September 26, 2006).

Below, we can see the Court's leading cases on the various aspects of transitional justice:

\footnotetext{
${ }^{1}$ Available in: <http://www.corteidh.or.cr/index.php/en/about-us/instrumentos>, Access in: 17 November 2017. Available in: <http://www.oas.org/dil/esp/tratados_B-32_ Convencion_Americana_sobre_Derechos_Humanos_firmas.htm\#Venezuela>. Access in: 17 November 2017.
} 
a) Velásquez Rodríguez vs. Honduras, July 29, 1988.

b) Benavides Cevallos vs. Ecuador, June 19, 1998.

c) Barrios Altos vs. Peru, March 14, 2001.

d) Goiburú et al. vs. Paraguay, September 22, 2006.

e) Almonacid Arellano et al. vs. Chile, September 26, 2006.

f) Gomes Lund et al. vs. Brazil ("Guerrilla of Araguaia"), November 24, 2010.

g) Gelman vs. Uruguay, February 24, 2011.

h) Masacres de Río Negro vs. Guatemala, September 4, 2012.

i) Tarazona Arrieta et al. vs. Peru, October 15, 2014.

Since 1988, with the Velásquez Rodríguez versus Honduras Case, the Court has settled its jurisprudence on the objectives of transitional justice (justice, truth, memory, reparations and institutional reforms) such as those considered in works of great scientific impact, by Ruti Teitel, Louis Bickford, Pablo de Greiff and others, and the Gomes Lund/"Guerrilla of Araguaia" Case of 2010, which involves a broad debate on the shortcomings of transitional justice in Brazil, is of particular interest, as I shall discuss in more detail ahead (TEITEL, 2015, p. 56-59; BICKFORD, 2004, p. 1.045-1.047; GREIFF, 2007, p. 26; GALINDO, 2017, p. 379-380).

\section{Brazil: difficulties of a "slow, gradual and secure" transitional justice...}

The long Brazilian military dictatorship (1964-1985) was at times somewhat paradoxical: for example, the period of the so-called "bullet years" in Brazil, between 1968 and 1975, was of great economic prosperity, to the point of being called a "Brazilian miracle" during the government of General President Emilio Médici; On the other hand, was the period of most brutal repression of political dissidents, and consequently, most of the crimes against humanity occurred precisely at that time, when the Institutional Act 5 was decreed by the military government in December 
1968, suspending the rights and fundamental guarantees that still had some protection, and giving dictators almost absolute powers to fight opponents. It was also during this period that several movements of armed struggle ascended, including the Guerrilla of Araguaia.

To describe how transitional justice has been in Brazil, I used this expression of the successor of Médici, General President Ernesto Geisel, who began a process of opening the regime from 1975 and stated at the time that Brazil would have a "slow, gradual and secure" transition to democracy.

In 1979, still in the authoritarian period, an Amnesty Law was passed, which allowed the return of many political exiles, as well as amnestied the majority of those convicted and persecuted for political motivation, although only with the Constitutional Amendment of 1985, it was possible to extend the amnesty to those who committed violent crimes in combat against the dictatorship. The amnesty has always been considered as bilateral (reaching State agents and political opponents), disregarding the concepts of political crime, criminal connection and crime against humanity (SILVA FILHO, 2015, p. 87 ss.).

As the Amnesty Law did not make able the punishment of criminals against humanity linked to the dictatorship, the first works of transitional justice in Brazil began within the scope of truth and memory and, later, reparation. It began with a research work in the accessible archives of the Brazilian Military Justice made in 1985 by a non-governmental team of researchers, coordinated by Paulo Evaristo Arns, Archbishop of the Catholic Church in São Paulo. The research report was published as a book entitled "Brazil: Never Again" (in Portuguese, "Brasil: Nunca Mais"). Then the Special Committee on Political Deaths and Disappearances, created in 1995, and in 2002 the Amnesty Commission of the Ministry of Justice was established on a permanent basis and also focused on reparations for the victims of the dictatorship (SILVA FILHO, 2015, p. 71-78; 168-207).

Regarding the question of the punishment of the State agents, in view of the IACHR jurisprudence on the impossibility of the State to amnesty its own agents, the Brazilian Bar Association filed a lawsuit with 
the Federal Supreme Court, questioning the traditional interpretation that Amnesty would reach them. However, most members of the Brazilian Court decided in April 2010 to maintain that traditional interpretation, reaffirming that no punishment could be applied, either to State agents or to the oppositionists who became involved in the armed struggle, since the Amnesty in Brazil would have been bilateral (STF, ADPF 153, Rel. Min. Eros Grau, April 29, 2010).

Nevertheless, in November of the same year, the IACHR judged the Gomes Lund/ "Guerrilla of Araguaia" Case in the opposite direction to what the Brazilian Court did (IACHR, Gomes Lund et al. vs. Brazil ("Guerrilla of Araguaia"), November 24, 2010). This case will be discussed below.

\section{The Gomes Lund "Guerrilla of Araguaia" case: Brazil's condemnation of the Inter-American Court of Human Rights and its political and legal consequences}

The Gomes Lund/“Guerrilla of Araguaia” case refers to the forced disappearance of 70 people in the Araguaia region, in the State of Pará, north of Brazil. The episode known as the "Guerrilla of Araguaia" happened between 1972 and 1975 in this region. So, the Communist Party of Brazil, in this illegal and clandestine era, decided to organize a guerrilla war in the fields of Araguaia to fight against the military dictatorship. But with few members (less than 80 against more than 10,000 soldiers from Armed Forces), and insufficient armaments and training, they were massacred by the official military forces and there were at the time of the investigation of the Inter-American Commission on Human Rights, 70 people involved in the episode considered victims of forced disappearance, due to the absence of information and explanations on the part of the Brazilian State regarding them (BRASIL, 2014, p. 717; KOIKE, 2014, p. 30-47).

Due to these facts and Brazil's inaction to carry out a broad process of transitional justice, the IACHR condemned Brazil for the violation of the Convention, establishing in particular that: 
Crimes against humanity are imprescriptible and cannot be amnestied: there is a Brazilian duty to investigate, prosecute and punish offenders against humanity;

The Brazilian State should investigate the whereabouts of missing persons, identify corpses and return them to families;

Acknowledgement of the responsibility of the Brazilian State for extrajudicial executions and enforced disappearances in the episode of the Guerrilla of Araguaia;

Also, the Brazilian State must create a commission of truth and take measures of remembrance and reparation in relation to the serious violations of human rights that occurred in that period. (IACHR, Gomes Lund et al. Brazil ("Guerrilla of Araguaia"), November 24, 2010)

Despite the resistance of the Brazilian judiciary, especially the Federal Supreme Court, to comply with the IACHR decision, it has had some important political and legal consequences. It is possible to highlight, among them:

The creation of the National Truth Commission in 2012 (12.528/2011 Act. The NTC commenced its work on May 16, 2012 and concluded its report on December 10, 2014)2;

Criminal lawsuits in relation to crimes committed after Amnesty Law, permanent crimes (as kidnapping, enforced disappearances and concealment of corpses) and remedies in respect of all crimes ${ }^{3}$; The proposal of a Bill in the Federal Senate that aims to give authentic interpretation (an interpretation by the parliament itself) to the Amnesty Law, expressly stating that it does not reach crimes against humanity committed by State agents (PLS 237/2013)4;

${ }^{2}$ 12.528/2011 Act. The NTC commenced its work on May 16, 2012 and concluded its report on December 10, 2014). Available in: <http://cnv.memoriasreveladas.gov.br/>. Access in: 20 November 2017.

${ }_{3}$ Available in: < http://www.mpf.mp.br/atuacao-tematica/pfdc/institucional/grupos-detrabalho/direito-a-memoria-e-a-verdade. Access in: 20 November 2017.

4 Available in: <https://www12.senado.leg.br/noticias/materias/2014/04/09/revisao-dalei-de-anistia-avanca-no-senado $>$. Access in: 20 November, 2017. 
The Brazilian Bar Association sued the Supreme Court with an appeal to clarify its former decision; and one of the Brazilian parties has filed a new lawsuit to review its former decision and to comply with the IACHR's verdict. (ADPF 153 and ADPF 320)

The IACHR decision, which occurred after the ADPF 153 judgment by the FSC, caused an epistemological embarrassment in the latter, which has so far failed to address the issue.

It is necessary to overcome such impasse, seeking theoretical output that bet on the dialogue between the courts.

\section{The Difficult Dialogue Between the Inter-American Court of Human Rights and the Federal Supreme Court: the trans- constitutional and co-evolutionary theoretical output}

In fact, it can be affirmed that there is a deadlock between the two courts. The IACHR charges the Brazilian State for full compliance with its Judgment, but Brazilian judiciary, especially the FSC, has postponed the decision on pending legal claims. There are difficulties in dialogue between the courts, as in other cases, which has been the subject of theoretical reflection by relevant Latin American authors. To explain some possibilities of making this dialogue viable, I bring two of them: Marcelo Neves, from Brazil, and Manuel Góngora-Mera, from Colombia, as theorists who propose interesting ways in this sense.

Firstly, Marcelo Neves and his theory of trans-constitutionalism. Neves argues that current constitutional law is embedded in a multilevel global legal system. Based on Niklas Luhmann's systems theory, he works on the ideas of double contingency, alterity and constitutional identity, relating them to the transverse rationality of the German

\footnotetext{
${ }_{5}^{5}$ ADPF 153, available in: <http://www.stf.jus.br/portal/processo/verProcessoAndamento. asp? incidente $=4574695>$. Access in: 20 November 2017. And ADPF 320, Available in: <http://www.stf.jus.br/portal/processo/verProcessoAndamento.asp? incidente $=4574695>$. Access in: 20 November 2017 . Both judicial actions have not been judged until now, after almost 6 years of the first and 3 of the second.
} 
philosopher Wolfgang Welsch, which would enable a rational dialogue between different legal systems (national, international, supranational, transnational and extra-state local legal orders). This dialogue would make possible learning from the "normative discoveries of the others" - an expression that Neves borrows from Jeremy Waldron, the famous New Zealander Professor -, and the theoretical framework of what Neves called transitional bridges, which would be the multidimensional articulation of different legal orders without a final decision-making body and the presence of methodological criteria decision-making rather than authority arguments (NEVES, 2009).

On the trans-constitutional relations between the Inter-American Human Rights System and the American national orders signatories to the Pact of San José, Neves points out that in cases decided by the Inter-American Court, we do not have a situation of mere hierarchical supremacy of the IACHR in relation to the national courts. The restriction of the jurisdiction of the Court to the interpretation of the Convention does not allow its interference in the internal affairs of States which, on the other hand, must observe the conventional law in their judgments. Even in Brazil, a historically "nationalist" country in relation to the internalization of public international law, the jurisprudence of the Federal Supreme Court has changed and in many respects has shown greater openness to the interpretations of the Court of San Jose in relation to the application of the Pact, as in the case of prohibition of the civil imprisonment of the unfaithful depositary, culminating, moreover, in a súmula vinculante, a sort of binding precedent for future cases. The supra-legal value of human rights treaties not approved according to the criteria of $\S 3$ of article 5 was a considerable advance of the jurisprudence of the highest Brazilian court in the sense of the trans-constitutional dialogue (NEVES, 2009, p. 144-147).

On the other hand, despite the fact that trans-constitutionalism works with a restrictive legal concept of supranationality, I understand that it applies to the IASHR, since it has, like the European System, strong supranational features, so that the thinking of Marcelo Neves on the relations between supranational law and national constitutional law are also relevant. 
Supranationality, in a narrow sense, is understood to be present only in cases where an organization based on an international treaty gives itself and its organs wide legislative, administrative and judicial powers, directly binding citizens and Member States. In this case, the thesis of "shared supremacy" in the inter-constitutional network is useful, since the situation of sharing of sovereign powers between national constitutions and the supranational constitution is evident (PIRES, 1997, p. 18; CANOTILHO, 2002, p. 1.409-1.414; GALINDO, 2006, p. 235 ss.; NEVES, 2009, p. 152-153). However, starting from this restrictive concept, trans-constitutionalism deals with these relations just in the example of the European Union, since only this entity could in strict terms be compatible with the aforementioned concept of supranationality.

On the basis of Weiler, Neves also points to the lack of a monolithic hierarchy between the constitutions of states and community law, betting on a constitutional "conversation" with reciprocal learning (NEVES, 2009, p. 154).

Since the 1960s, the European Court of Justice has established the primacy of Community law over national law, as in the case of Costa/ E.N.E.L. (1964) and Simmenthal (1978) (GALINDO, 2006, p. 230). However, this direct attachment has never been unrestricted: although this primacy is not denied by the national constitutional courts, it is often relativized and can be disregarded when it does not fulfill certain preconditions established by the constitutional law of the Member State (NEVES, 2009, p 154).

Especially the German experience is very rich in the emblematic leading cases Solange I (1974) and Solange II (1986), judged by the Federal Constitutional Court, as well as later with the amendment of the wording of article 23 of its Basic Law. The so-called "formula-while" was an artifice used by the German FCC to prevent its being withdrawn from its jurisdiction to examine the constitutionality of a provision of Community law if it conflicted with the constitutional rules protecting fundamental rights (HESSE, 1998, p. 98-102; GALINDO, 2006, p. 237ff). That is to say, although Community primacy is the general rule, the FCC has reserved itself a kind of "last word of emergency" when 
the Community rules do not protect fundamental rights as much as the German Basic Law. This political stance of giving the last word, although in the speech the FCC asserts that such decisions must be taken in cooperation with the Court of Justice of the European Union, is seen as an absence of dialogical disposition by authors such as Joseph Weiler, which may lead to relevant blocking problems at constitutional talks (NEVES, 2009, p. 158-159). The same problem can occur when supreme courts or constitutional tribunals within the IAHRS simply refuse to comply with the decisions of the Inter-American Court, adopting what another author, Góngora-Mera, calls a nationalist unidirectionalism, as seen below.

And last, but not least, Manuel Góngora-Mera and his theory of coevolutionism. This author discusses the relationship between national and supranational courts with IACHR case studies.

For him, there are 3 possible models of compatibility between decisions of national courts and the regional court: 1) unidirectional in favour of the national court; 2) unidirectional in favour of the regional court; 3) multidirectional (interdependent) (GÓNGORA-MERA, 2013, p. 336).

The first, unidirectional model in favour of the national courts would imply little concrete relevance to the solutions given by the Inter-American Court, leaving to the national courts a high margin of appreciation when interpreting and applying the Convention. National adherence to it tends to be minimal and convergence between systems appears to be weak. As a consequence, there is a greater risk of systematic rejection of the rules of IAHRS and also inter-judicial conflicts between the national courts and the Inter-American Court. As examples of this nationalist unidirectionalism, one can cite the Diaz Peña Case (2012) involving the decision of the Supreme Court of Justice of Venezuela and the withdrawal of that country from the Inter-American System and the Gomes Lund/“Guerrilla of Araguaia” Case (2010), until now without concrete responses from the Brazilian STF regarding compliance with the judgment of the Inter-American Court in relation to the possibility of punishment of the perpetrators of crimes against humanity.

The second model, unidirectional in favour of the regional court, would imply the prevalence of the decisions of the Inter-American 
Court, leaving to the national courts a limited margin of appreciation when interpreting and applying the Convention. National adherence to it tends to be maximal and convergence between systems is variable. As a consequence, there is a convergence through persuasion, but a serious risk of uncritical reception of the Inter-American Court's understandings, with no space for eventual better national solutions for the assertion of conventional rights. As examples of this regional unidirectionalism, one can cite the case of the receipt of the Inter-American Court's understanding of the Convention 169 of the International Labor Organization by the Supreme Court of Costa Rica (1995), and it is also possible to add transitional justice cases judged in Argentina, such as Arancibia Clavel (2004) and Mazzeo, Julio Lilo and Others (2007). It is also important to remember that the Constitutional Reform of 1994 in the Argentinian Constitution explicitly enshrined the ACHR as a constitutional norm (article 75, 22).

Last, but not least, and similar to Neves, Góngora-Mera proposes a third model as superior to previous ones in the co-evolutionary approach. The multidirectional and interdependent theoretical approach between the two normative spheres of the courts, admitting the margin of appreciation, not in the sense of the prevalence of one or another court in terms of authority, but from the pro homine principle, in perspective of maximizing the effectiveness of the conventional human rights. In this case, national adherence would be medium and deliberative, but convergence would tend to be strong. In this context, the influences between IACHR and the national courts are reciprocal and this pro homine convergence results in a discursive reception of conventional rights by both courts involved. So, the author speaks of the possibility of top-down convergences, with the national court accepting the broader scope of the Inter-American System and the IACHR decisions, as in this case involving the Brazilian Supreme Court about the old Brazilian Press Law; And bottom-up convergences, with the national court influencing IACHR by the broader scope of the national system for the protection of conventional human rights, as can be exemplified in this case involving the Colombian Constitutional 
Court, about prior consultation with indigenous population (GÓNGORAMERA, 2013, p. 333-334). ${ }^{6}$

It appears that theoretical contributions such as these can help overcome the current dialogical impasse between IACHR and the Brazilian Court. Thinking, for example, in the perspective of transconstitutionalism, a new Supreme Court decision could reaffirm its authority as interpreter of the Constitution and that the Amnesty Law is constitutional. However, at the same time, to emphasize that Brazil must fulfill its commitments under international (or supranational) law and that, since IACHR is the interpreter of the ACHR, the Brazilian State must comply with its decisions, since it has committed itself to this. So we would also refer to a possible top-down convergence, which would not be a novelty in Brazil, as we have seen. And Brazil would fulfill its obligations to the IASHR also with regard to investigating, prosecuting and punishing the perpetrators of crimes against humanity of the dictatorship.

\section{From "Never Again" to the Eternal Return of Authoritarianism: some conclusions}

Considering that Brazil has partially fulfilled the Gomes Lund Sentence, especially in the fields of memory and truth, it is possible to inquire: what is the importance of making a more comprehensive transitional justice in Brazil, including the punishment of criminals against humanity, long after the end of the military dictatorship?

Some possible answers may be the ones that follow.

Brazil still demonstrates a significant lack of democratic and humanistic culture, in the population in general and in its institutions. And this is accentuated in moments of crisis, like the current one.

\footnotetext{
${ }^{6}$ The Colombian Professor is still dealing with a third type of convergence, the horizontal convergence, when constitutional courts adopt judicial understandings of other national courts of the IAHRS, directly or through the Inter-American Court. However, it does not deepen this third type of multidirectional interaction in the cited paper (GÓNGORAMERA, 2013, p. 333).
} 
Recent research conducted by Brazilian Forum on Public Security about the propensity of Brazilian citizens to support authoritarian actions in some situations, reaching the staggering level of $81 \%$ if actions are to combat the high rates of urban violence ${ }^{7}$ (FÓRUM BRASILEIRO DE SEGURANÇA PÚBLICA, 2017). The annual surveys carried out by the Chilean NGO, Latinobarómetro, expose the instability of the Brazilian population's support for democracy as a political regime, with index of $54 \%$ in $2015,32 \%$ in 2016 and $43 \%$ in 2017 , being the greatest oscillations among all the Latin American countries surveyed (LATINOBARÓMETRO, 2017, p. 13). In addition, the Brazilian Institute of Opinion Research (IPO) found in 2014 that a significant part of the Brazilian population has a negative view of what human rights are, especially when regarding prisoners (IPO, 2014, p. 116).

All this is reflected in the current conjuncture of fragile democracy and the weakening of human rights in Brazil, in examples such as these:

An impeachment last year of an elected President of the Republic as a controversial action without constitutional grounds, in my point of view (Galindo: 2016);

The current constitutional reforms in Brazil (labor and social security reforms, privatizations, restrictions on public investments, etc.) as, in practice, a repeal of the welfare state constitution without electoral or constituent power;

An increase of authoritarian practices and breaches of constitutional guarantees and fundamental rights by the judiciary, public prosecutors and law enforcement agents in the name of combating corruption, in the case of the "Car Wash" Operation ${ }^{8}$ and others.

\footnotetext{
7 Available in: <http://www.huffpostbrasil.com/2017/10/06/apoio-ao-autoritarismo-nobrasil-e-8-1-em-escala-de-0-a-10_a_23235365>. Access in: $1^{\circ}$ January 2018.

8 The so-called "Car Wash" Operation (Operação Lava Jato) consists of a set of investigations, prosecutions and decisions in the police and judicial scope initiated in 2014 that has already become a landmark of the discovery and punishment of corrupt in Brazil, something historically neglected in terms of punishability, and reached large entrepreneurs to powerful politicians, especially of the Workers' Party, who was in charge of the government until April 2016, when then-President Dilma Roussef was deposed in a controversial impeachment process; despite this, the judges, prosecutors
} 
However, probably the most troubling is the rise of a political discourse of explicit approval of the military dictatorship and of defense of authoritarian solutions to the current problems of Brazil. In particular, two recent facts make this hypothesis plausible.

On the one hand, the recent statements of General Amilton Mourão that if the judiciary and the politicians did not solve the problems of corruption, the military themselves would do so, in a clear insinuation of the possibility of a new coup d'etat in Brazil'. Initially, he did not suffer any disciplinary action or punishment for his first statement and only after repeated statements in the same sense, he was removed from his duties by his superiors in December $2017^{10}$.

On the other hand, Brazil has predicted in its electoral calendar the holding of elections for President of the Republic in 2018. And one of the strongest candidates according to the most recent opinion polls is Jair Bolsonaro, a representative in the National Congress (the Parliament in Brazil) and a former captain of Brazilian Army who openly defends the military dictatorship. He appears as a leader in opinion polls on the vote of Brazilian voters in the October 2018 elections. At this conjuncture, Bolsonaro would be a favorite in the presidential elections of $2018^{11}$. This is the Brazilian scenario for 2018 , at least for now.

So, it is possible to say that from what we have been researching in relation to other experiences of transitional justice and comparing them with

and law enforcement agents associated with the Operation have been criticized in their heterodox interpretations of the Constitution and rules, disrespecting fundamental rights and guarantees from deeply controversial measures in the context of the rule of law in a democratic State, as well as for violations of the duties of impartiality and exemption, and associations with large national media corporations. But because it is an ongoing phenomenon, any analysis runs a huge risk of being wrong.

9 Available in: <http://www.digitaljournal.com/news/world/general-s-interventioncomment-raises-eyebrows-in-brazil/article/503220>. Access in: $1^{\circ}$ January, 2018.

10 Available in: <http://www.correiobraziliense.com.br/app/noticia/brasil/2017/12/09/ internas_polbraeco,646767/3-meses-apos-defender-intervencao-militar-general-doexercito-e-afa.shtml $>$, Access in: $1^{\circ}$ January, 2018.

11 Available in: <https://www.infomoney.com.br/mercados/politica/noticia/7527531/ sem-lula-bolsonaro-lidera-corrida-presidencial-com-pelo-menos-pontos $>$, Access in: 8 August, 2018. Recently, General Mourão accepted an invitation to be a candidate for Vice-President in the same coalition of Jair Bolsonaro. 
the Brazilian one, we could see, at least momentarily, that the difficulties of carrying forward a genuine transitional justice process in Brazil are likely to have a considerable influence on the institutional and social weakness of our democratic culture and respect for human rights, which in our country still seems to be an unfinished and completely open endeavour.

The feeling I have (and I think science is also feeling, not just data) is that, even after the delayed implementation of transitional justice, judgments of criminals against humanity, along with the intensification of other transitional justice actions and measures, could have an important pedagogical effect, as has happened with our neighbours Chile and Argentina, for example, where it seems to be more difficult to return to authoritarian regimes or governments. And the support for democracy and human rights is considerable superior than occurs in Brazil.

\section{References}

ARNS, Paulo Evaristo. Um Relato para a História: Brasil: Nunca Mais, 38. ed. Petrópolis: Vozes, 2009.

BAZÁN, Victor. El control de convencionalidad como instrumento para proteger derechos esenciales y prevenir la responsabilidad internacional del Estado. Anuario Iberoamericano de Justicia Constitucional, Madrid, Centro de Estudios Políticos y Constitucionales, n. 19, p. 25-70, 2015. Available in: $<$ http//:dx.doi.org/10.18042/cepc/aijc.19.02>.

BICKFORD, Louis. Transitional justice. The Encyclopedia of Genocide and Crimes Against Humanity, Michigan: Macmillan Reference USA, V. 3, p. 1.045-1.047, 2004.

BRASIL. Comissão Nacional da Verdade: Relatório. Brasília: CNV, 2014. $976 \mathrm{p}$.

CANOTILHO, José Joaquim Gomes. Direito Constitucional e Teoria da Constituição. 6th ed. Coimbra: Almedina, 2002.

FERRER MACGREGOR, Eduardo. The Constitutionalization of International Law in Latin America: Conventionality Control The New Doctrine of the Inter-American Court of Human Rights", 2015. Available 
in: $<$ https://www.asil.org/blogs/symposium-constitutionalizationinternational-law-latin-america-conventionality-control-new $>$, Access in: 7 March 2017.

FÓRUM BRASILEIRO DE SEGURANÇA PÚBLICA. Medo da violência e o apoio ao autoritarismo no Brasil. São Paulo: Fórum Brasileiro de Segurança Pública, 2017.

GALINDO, Bruno. Constitucionalismo e justiça de transição: em busca de uma metodologia de análise a partir dos conceitos de autoritarismo e democracia. Revista da Faculdade de Direito da Universidade Federal de Minas Gerais, Belo Horizonte: UFMG, n. 67, p. 100-102, 2015.

GALINDO, Bruno. Impeachment à luz do constitucionalismo contemporâneo. Curitiba: Juruá, 2016.

GALINDO, Bruno. Justiça de transição em sua gênese: a Alemanha pósnazismo. Revista de Direito Internacional, Brasília: UniCeub, v. 14, n. 1. p. 377-401, 2017.

GALINDO, Bruno. Teoria Intercultural da Constituição. Porto Alegre: Livraria do Advogado, 2006.

GARCÍA RAMÍREZ, Sergio. Relación entre la jurisdicción interamericana y los Estados (sistemas nacionales). Algunas cuestiones relevantes. Anuario Iberoamericano de Justicia Constitucional, Madrid: Centro de Estudios Políticos y Constitucionales, n. 18, p. 231273, 2014. Available in: <http://www.corteidh.or.cr/index.php/en/aboutus/instrumentos $>$. Access in: 17 November 2017.

GARCÍA RAMÍREZ, Sergio; MORALES SÁNCHEZ, Julieta. Hacia el ius commune interamericano: la jurisprudencia de la Corte IDH em 20132016. Anuario Iberoamericano de Justicia Constitucional, Madrid: Centro de Estudios Políticos y Constitucionales, n. 20, p. 433-463, 2016. GÓNGORA-MERA, Manuel Eduardo. Interacciones y convergencias entre la Corte Interamericana de Derechos Humanos y los tribunales constitucionales nacionales: un enfoque coevolutivo. In: BOGDANDY, Armin von; PIOVESAN, Flávia; MORALES ANTONIAZZI, Mariela. (Org.). Estudos avançados de direitos humanos. Rio de Janeiro: Elsevier, 2013. p. 312-337. 
GREIFF, Pablo de. La contribución de la justicia transicional a la construcción y consolidación de la democracia. In: BLEEKER, Mô; CIURLIZZA, Javier; BOLAÑOS-VARGAS, Andrea. (Org.). Memorias: Conference Paper. Bogotá: ICTJ, 2007. p. 25-35.

IPO - INSTITUTO PESQUISA DE OPINIÃO. Direitos Humanos: percepções da opinião pública (Relatório de Pesquisa). Porto Alegre: IPO, 2014.

KOIKE, Maria Lygia de Almeida; Silva. O direito à verdade e à memória no caso da Guerrilha do Araguaia. Coimbra, 2014.

LATINOBARÓMETRO. Informe 2017. Santiago: Latinobarómetro, 2017.

NEVES, Marcelo. Transconstitucionalismo. São Paulo: WMF Martins Fontes, 2009. (There is an English translation - NEVES, Marcelo. Transconstitutionalism: translated by Kevin Mundy. Oxford and Portland Oregon: Hart Publishing, 2013).

PIRES, Francisco Lucas. Introdução ao Direito Constitucional Europeu. Coimbra: Almedina, 1997.

SILVA FILHO, José Carlos Moreira. Justiça de transição: da ditadura civil-militar ao debate justransicional. Porto Alegre: Livraria do Advogado, 2015.

TEITEL, Ruti G. Globalizing transitional justice: contemporary essays. Oxford: University Press, 2014.

Bruno Galindo é professor permanente, de direito constitucional, do Programa de Pós-Graduação em Direito da Universidade Federal de Pernambuco. E-mails: brunogalindoufpe@gmail.com; brunogalindo@uol.com.br. Endereço profissional: Praça Adolfo Cirne, s/n., Boa Vista, Recife/PE, CEP: 50050-060. 